\title{
VIBRATION REDUCTION SYSTEM USING MAGNETIC SUSPENSION TECHNOLOGY
}

\section{UKŁAD REDUKCJI DRGAŃ Z ZASTOSOWANIEM TECHNOLOGII ZAWIESZEŃ MAGNETYCZNYCH}

\author{
Jarosław Spychała, Mariusz Żokowski, Pawel Majewski \\ Instytut Techniczny Wojsk Lotniczych \\ e-mail: jaroslaw.spychala@itwl.pl,mariusz.zokowski@itwl.pl, \\ pawel.majewski@itwl.pl
}

\begin{abstract}
The article presents considerations concerning the construction of vibration reduction system using magnetic suspension technology. Presents the results of simulation, numerical and experimental the bearingless electric motor, for which successfully used this type of solution. Positive results of research and testing have become the basis for the development of the concept of building this type of active vibration reduction system, at the same time acting as a support for a technical object, which is a jet engine. Bearing failures are manifested by loss or distortion of their mass, which leads to a total destruction of the roller bearing, and thus reflected in the security. The article presents the concept of building active magnetic suspension to eliminate the bearing system of classical rolling bearing and replace it with magnetic bearing.
\end{abstract}

Keywords: active magnetic bearing, suspension technology.

Streszczenie: $W$ artykule przedstawiono rozważania, dotyczace budowy uktadu redukcji drgań z zastosowaniem technologii zawieszeń magnetycznych. Przedstawiono wyniki badań symulacyjnych, numerycznych $i$ eksperymentalnych samołożyskującego się silnika elektrycznego, dla którego z sukcesem zastosowano tego typu rozwiazanie. Pozytywne wyniki badań i testów staty się podstawa do opracowania koncepcji budowy tego typu uktadu aktywnej redukcji drgań, petniacego zarazem funkcje podpory dla obiektu technicznego, jakim jest silnik odrzutowy. Defekty tożysk objawiaja się ubytkiem lub znieksztatceniem ich masy, co w konsekwencji prowadzi do całkowitego zniszczenia łożyska tocznego, a co za tym idzie przeklada się na bezpieczeństwo. $W$ artykule zostanie przedstawiona koncepcja budowy zespotu aktywnego zawieszenia magnetycznego $w$ celu eliminacji z uktadu tożyskowania klasycznego tożyska tocznego i zastapienie go tożyskiem magnetycznym.

Stowa kluczowe: aktywne tożysko magnetyczne, technologia zawieszeń. 


\section{Wstęp}

Wirujące maszyny przepływowe, takie jak generatory elektrowni wiatrowych, śruby napędowe okrętów, wentylatory odsiarczania spalin czy też wały wirników silników odrzutowych, są złożonymi obiektami technicznymi, które łączą w sobie wiele wymagających technologicznie komponentów. Każdy $\mathrm{z}$ nich powinien cechować się wysoką niezawodnością i trwałością, a najbardziej krytyczne elementy powinny również posiadać układy monitorowania zmiany ich stanu technicznego.

Jednym $\mathrm{z}$ takich komponentów jest system mocowania zespołów wirujących w korpusie danej maszyny, wykonany w oparciu o klasyczne łożyska mechaniczne. Jednakże łożyska tego typu to najczęściej uszkadzające się elementy pracujących maszyn. Wynika to $\mathrm{z}$ faktu, iż to właśnie one bezpośrednio odpowiadają za przeniesienie ruchu, a tym samym narażone są na największe obciążenia. Spełnienie określonych wymagań, takich jak: dobra odkształcalność, odporność na zatarcie, zużycie i korozję, wytrzymałość na nacisk w temperaturze pracy, wytrzymałość zmęczeniowa, dobre przewodnictwo cieplne, to wymagane cechy materiału konstrukcyjnego łożyska. Aby je zachować wymagana jest również właściwa eksploatacja urządzenia, a przede wszystkim diagnostyka i ich ciągła konserwacja.

Postawienie właściwej diagnozy oraz wczesna detekcja potencjalnej awarii w celu minimalizacji przerw w produkcji oraz kosztów - to dwa kluczowe problemy nowoczesnych służb utrzymania ruchu.

Doświadczenia płynące $\mathrm{z}$ eksploatacji różnych typów maszyn wirnikowych pokazują, że pomimo starannego doboru klasycznego łożyska realizowanego na etapie konstruowania, zwykle dokonywanego w oparciu o nośność, trwałość i warunki pracy łożyska, a także eksperymentalne modele zmęczenia materiału współpracujących par kinematycznych (służące do wyznaczenia żywotności łożyska), często dochodzi do ich uszkodzenia. Stosowane również systemy monitorowania (np. pomiar drgań na korpusie maszyny, badanie zawartości produktów zużycia w oleju smarującym, itp.), nie zawsze dostarczają jednoznacznie identyfikowalnej informacji diagnostycznej. Złożoność sygnału wibroakustycznego, pochodzącego ze złożonego obiektu technicznego może rodzić trudności w jego jednoznacznej analizie, a badanie zawartości produktów zużycia pochodzących $\mathrm{z}$ dużej liczby par tribologicznych w oleju smarującym, także nie zawsze pozwala na wskazanie przyczyny zachodzących zmian.

Zasadnym jest, więc opracowywanie i rozwijanie technologii, mogących zastąpić klasyczny sposób osadzenia wykonujących ruch obrotowy zespołów składowych maszyn, szczególnie tych wymagających i odpowiedzialnych. 


\section{Aktywne zawieszenie magnetyczne w silniku elektrycznym}

Zawieszenia magnetyczne pozwalają na zawieszenie wału wirnika bez mechanicznego kontaktu, używając jedynie siły przyciągania magnetycznego, która jest odpowiednio sterowana, poprzez pomiar odległości wału wirnika od czujników mierzących jego przemieszczenie w pętli sprzężenia zwrotnego, w której skład wchodzą czujniki przemieszczeń (wiroprądowe, indukcyjne, optyczne), elektromagnesy, regulatory i wzmacniacze / zasilacze mocy. Posiadają one bardzo wiele zalet $\mathrm{w}$ porównaniu do tradycyjnych metod łożyskowania (toczne, ślizgowe). Do głównych zalet należą przede wszystkim:

- duża niezawodność rozwiązania, brak konieczności smarowania,

- bezkontaktowe łożyskowanie wirnika,

- niski poziom drgań,

- precyzyjne sterowanie ruchem wału wirnika,

- praca z dużymi prędkościami obrotowymi,

- niskie zużycie energii,

- aktywna redukcja drgań poprzez układ sterowania,

- diagnostyka oraz identyfikacja parametrów maszyny wirnikowej.

Możliwości technologiczne i funkcjonalne łożyska magnetycznego potwierdzono w oparciu o zbudowany, rzeczywisty model laboratoryjny bezłożyskowego silnika elektrycznego. W układzie tym wyeliminowano klasyczne łożyska mechaniczne, zastępując je aktywnym zawieszeniem magnetycznym.

Stanowisko laboratoryjne $\mathrm{z}$ zabudowanym modułem bezłożyskowego wirnika silnika elektrycznego, przedstawiono na Rys. 1.

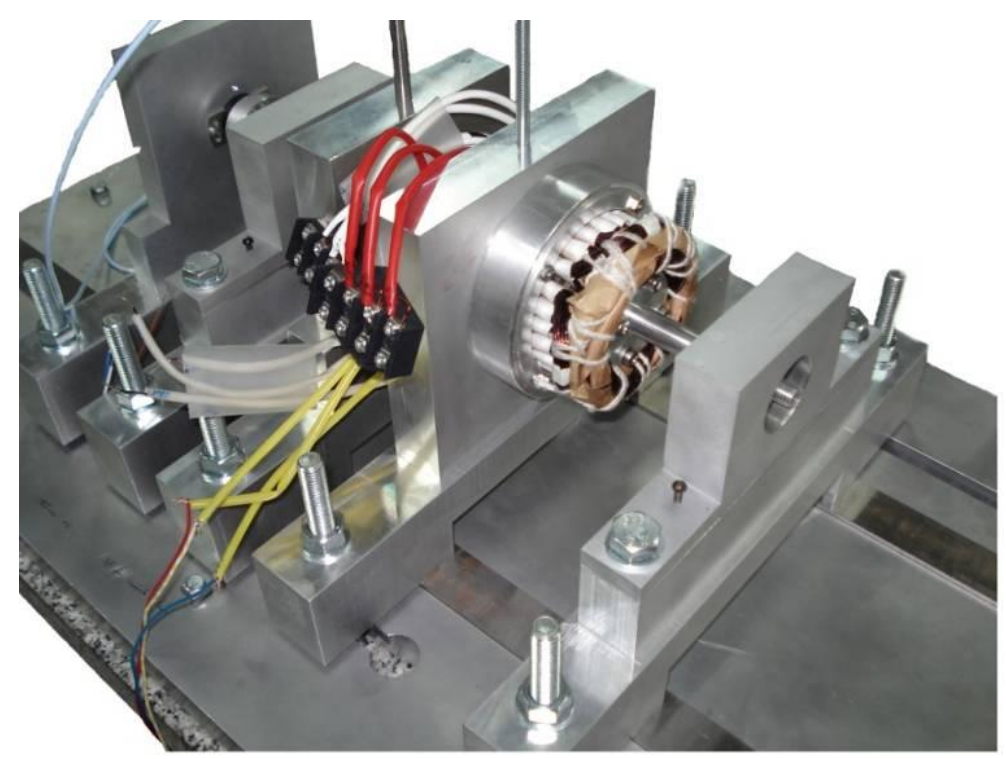

Rys. 1. Stanowisko laboratoryjne z bezłożyskowym silnikiem elektrycznym. 
Przedstawiony silnik posiada 24 żłobki, w których zostały umieszczone czterobiegunowe uzwojenia silnikowe (do generowania momentu obrotowego) i dwubiegunowe uzwojenia, przeznaczone do lewitacji magnetycznej wirnika silnika.

Rysunek $\mathrm{nr} 2$ przedstawia stator bezłożyskowego silnika elektrycznego z nawiniętymi na nim trójfazowymi uzwojeniami:

- $N_{4 a}, N_{4 b}, N_{4 c}-$ uzwojenia silnikowe, które wytwarzają (generują) moment obrotowy;

- $N_{2 a}, \quad N_{2 b}, \quad N_{2 c}$ - uzwojenia łożyskowe, które generują siły utrzymujące w stanie lewitacji magnetycznej wał wirnika silnika.

Uzwojenia przeznaczone do wytwarzania momentu obrotowego silnika oznaczone zostały na rysunku jako $N_{4}$. Chwilowa wartość prądu została oznaczona została jako $i$. Wymnażając przez siebie ilość uzwojeń i chwilową wartość prądu płynącego w cewce można wyznaczyć siłę magnetomotoryczną $F_{m}=\left(N_{4} \cdot i\right)$.

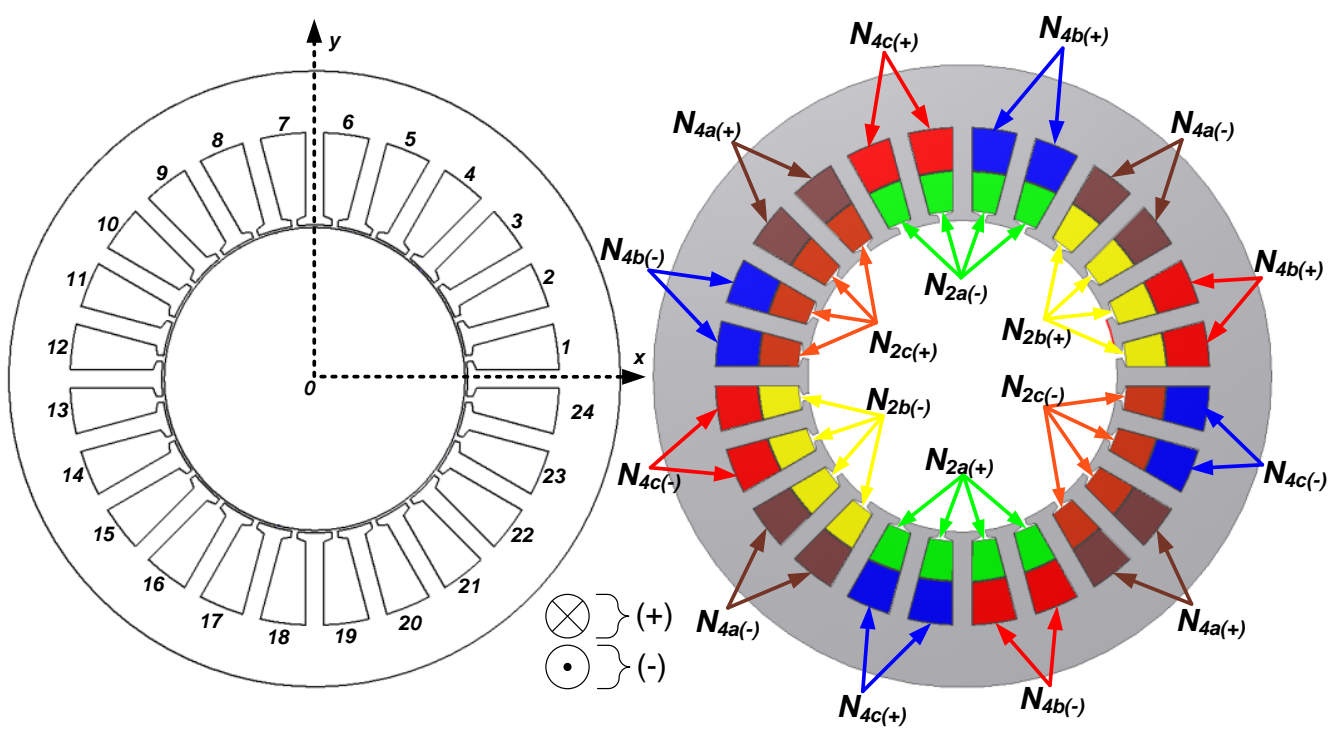

Rys. 2. Rozmieszczenie uzwojeń na statorze projektowanego silnika.

Szczelina powietrzna oznaczona została jako $x_{0}$ (położenie centralne wału wirnika silnika). Kierunki przemieszczeń w układzie współrzędnych Oxy zostały zdefiniowane jako $x$ i $y$, odpowiednio w kierunku osi $0 x \rightarrow x$ i w kierunku osi $O y \rightarrow y$.

Za stabilizację ruchu wału wirnika w kierunku promieniowym odpowiedzialne jest jedno z rodzajów uzwojeń nawiniętych na statorze silnika zgodnie z zasadą liczby 
par biegunów $p \pm 1$. Wynika to $\mathrm{z}$ faktu, że w konstrukcji tego typu silników jedno z uzwojeń (łożyskowe) musi być modulowane do napięć zasilających uzwojenie silnikowe z dwa razy mniejszą częstotliwością zasilania. Nie ma reguły, które uzwojenie wykona się jako czterobiegunowe bądź dwubiegunowe, zasadą jest tylko utrzymanie liczby par biegunów $p \pm 1$.

Jedno z uzwojeń $\rightarrow$ czterobiegunowe przeznaczone jest do wytwarzania momentu obrotowego maszyny, natomiast drugie, dwubiegunowe jest odpowiedzialne za lewitację magnetyczną wirnika silnika [1], [2].

\section{Badania eksperymentalne aktywnego zawieszenia magnetycznego}

W oparciu o zrealizowane prace analityczne (badania symulacyjne, numeryczne) oraz eksperymentalne bezłożyskowego silnika elektrycznego, można stwierdzić, że możliwe jest zbudowanie układu aktywnej redukcji drgań dla maszyny, zapewniającego odpowiednie parametry pracy (odporność na wysokie drgania, wymuszenia od przepływów, duże obciążenia dynamiczne i termiczne, funkcjonowanie $\mathrm{w}$ pełnym zakresie zmian prędkości obrotowej wirnika).

Poniżej przedstawiono wybrane dane z badań symulacyjnych, numerycznych i eksperymentalnych, które potwierdzają zasadność prowadzenia tego typu prac na wymagającym obiekcie technicznym. Ze względu na konieczność spełnienia odpowiednio wysokich warunków pracy, zasoby technologiczne (posiadanie sprawnej maszyny przepływowej) i odpowiednie zaplecze (hamownia i zdolności obsługowo-montażowe) planuje się podjąć tego typu prace badawcze na silniku odrzutowym.

$\mathrm{Na}$ rysunku $3 \mathrm{a}$ i $3 \mathrm{~b}$ przedstawiono schematyczny rozkład pola generowanego przez dwufazowe uzwojenie silnikowe $N_{4 a}$, wraz z zamodelowanym rozkładem pola generowanego przez uzwojenia $\mathrm{z}$ wykorzystaniem środowiska Comsol Multiphysics.

Dodatkowo dla silnika bezłożyskowego przeprowadzono badania numeryczne, które potwierdzono eksperymentalnie. Wyniki badań numerycznych rozkładu indukcji magnetycznej oraz badań eksperymentalnych przedstawiono na Rys. 4. Wyniki numeryczne ze względu na idealizację zjawisk odbiegają od wyników eksperymentalnych, ponieważ w warunkach rzeczywistych sonda pomiarowa dotykała bezpośrednio powierzchni zębów statora, nie przylegając całkowicie do niego. Jednakże charakter przebiegu rozkładu indukcji magnetycznej na obwodzie stojana jest taki sam, co potwierdza poprawność wykonania uzwojeń silnikowych i łożyskowych a zarazem weryfikuje opracowany komputerowy model numeryczny. 
a)

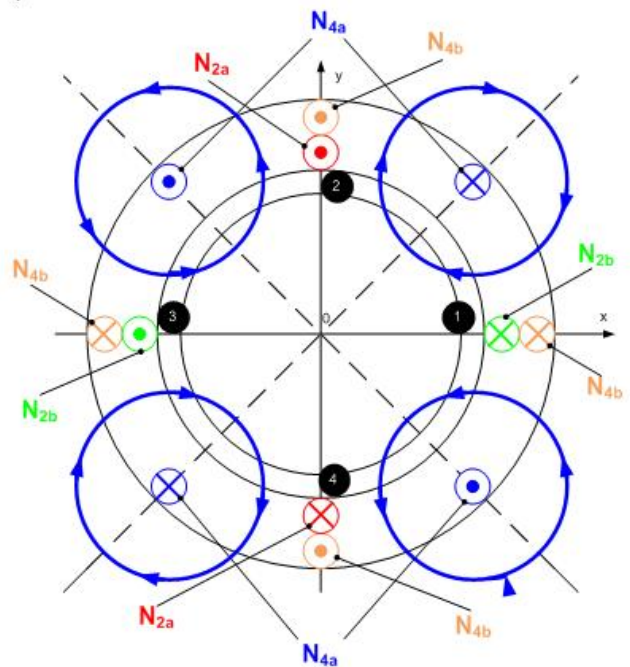

b)

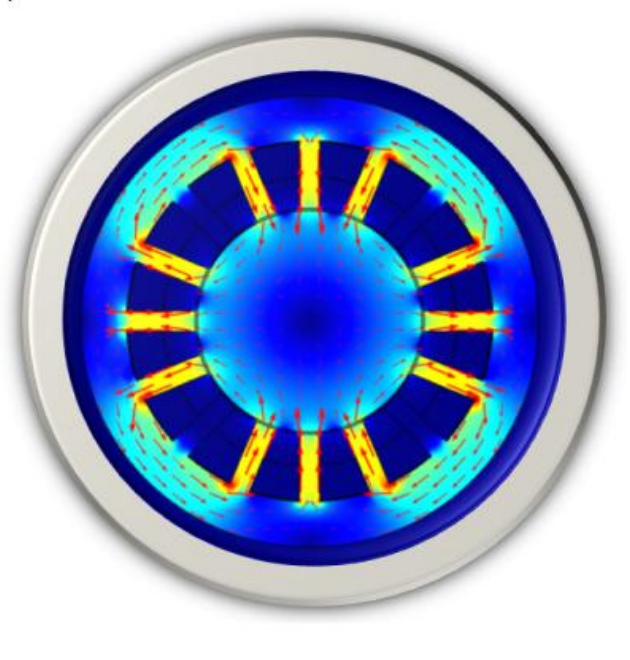

Rys. 3. Pole magnetyczne generowane przez dwufazowe uzwojenie silnikowe N4a. a) strumień $4 a$ generowany przez faze 4a, b) faza 4 a zamodelowana w MES'ie.

a)

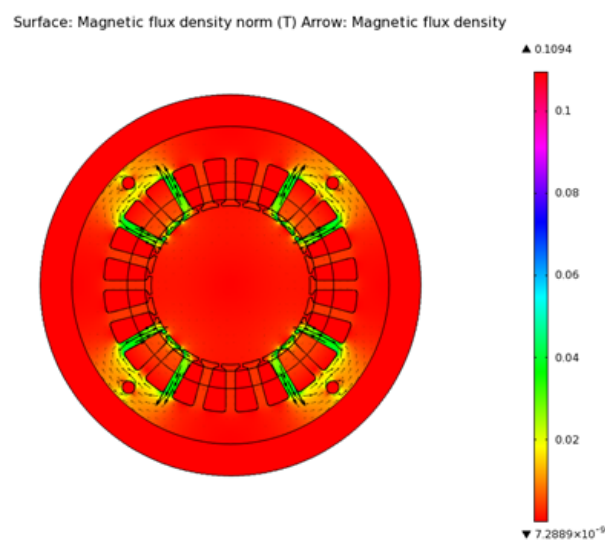

b)

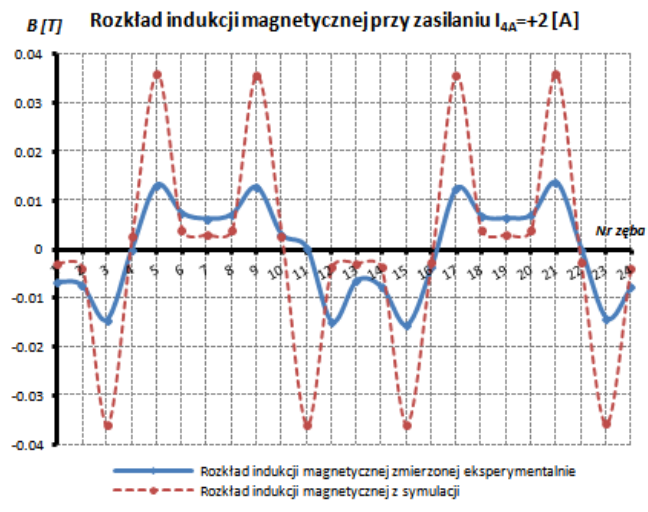

Rys. 4. Rozktad indukcji magnetycznej na zębach statora silnika:

a) badania numeryczne fazy silnikowej $4 A$;

b) rozklad indukcji magn. (symulacja, eksperyment) fazy silnikowej 4 A.

Wyniki badań eksperymentalnych przedstawionego układu samołożyskującego się silnika elektrycznego, potwierdziły jego badania symulacyjne i numeryczne. Zgodność modelu numerycznego i eksperymentalnego przedstawiono dla wybranej fazy silnikowej (faza 4A) na poniższym rysunku. W modelu numerycznym 
modelowano rozkład indukcji magnetycznej na zębach statora (Rys. 4a), natomiast weryfikacja modelu numerycznego nastąpiła po wykonaniu pomiarów rozkładu indukcji magnetycznej na zębach statoraz wykorzystaniem gaussomierza, przy zasilaniu fazy prądem stałym o wartości 2 [A]. Na podstawie przeprowadzonych badań wydaje się, że możliwym będzie zbudowanie układu aktywnej redukcji drgań $\mathrm{W}$ zastosowaniu do innego obiektu technicznego, pod warunkiem zapewnienia prądu punktu pracy takiego łożyska. W analizowanym przypadku prąd punktu pracy zapewniały uzwojenia silnikowe.

Dla opisywanego samołożyskującego się silnika, wykonane zostały również badania częstotliwościowe, które pozwalają na opis dynamiki takiego silnika. Parametry takie, jak: częstotliwości własne, pasmo przenoszenia oraz wzmocnienia są bardzo ważną informacją, opisującą pracę silnika. Pozwalają one dobrać odpowiednio nastawy regulatora oraz prognozować zachowanie się układ w danych warunkach pracy [2]. Schemat takiego podłączenia pokazano na Rys. 5.

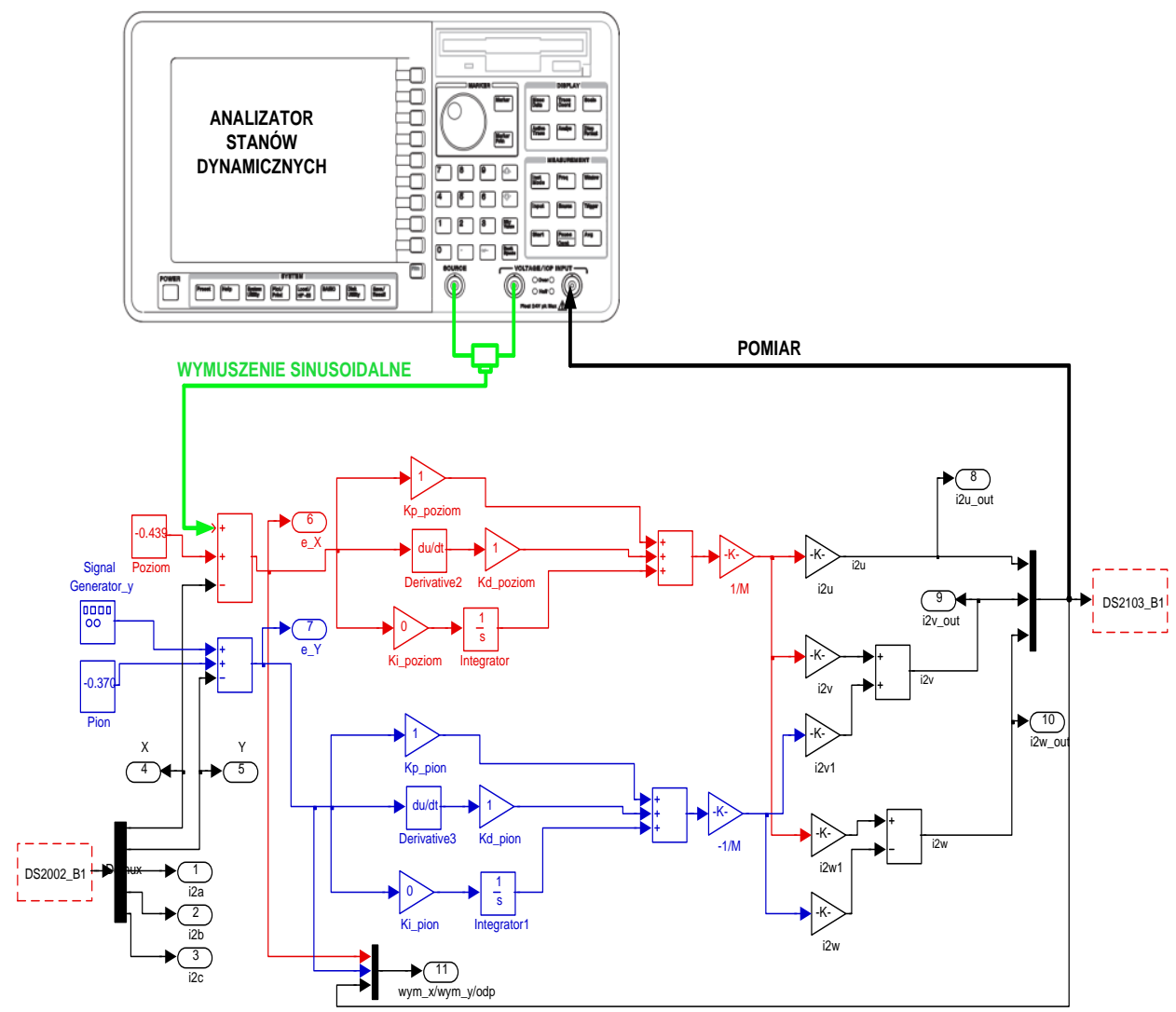

Rys. 5. Schemat połaczeń uktadu sterowania

$z$ analizatorem stanów dynamicznych. 
Badania w dziedzinie częstotliwości zostały przeprowadzone przy wymuszeniu sygnałem sinusoidalnym $\mathrm{w}$ kanale $O x \quad \mathrm{z}$ regulatorem typu PID o następujących nastawach regulatora $K_{p}=90, K_{d}=0.4, K_{i}=10$. Na Rys. 6 przedstawiono charakterystykę Bode'go dla kanału $O x$ uzwojeń łożyskowych $\mathrm{z}$ regulatorem PID. Prąd punktu pracy wynosił $i_{0}=1[\mathrm{~A}]$.

Charakterystyka Bode'go przy wymuszeniu sygnałem sinusoidalnym 0.05 [mm] w granicach od 1 [Hz] do 1 [kHz] $i_{0}=1[A], K_{p}=90, K_{d}=0.4, K_{i}=10$
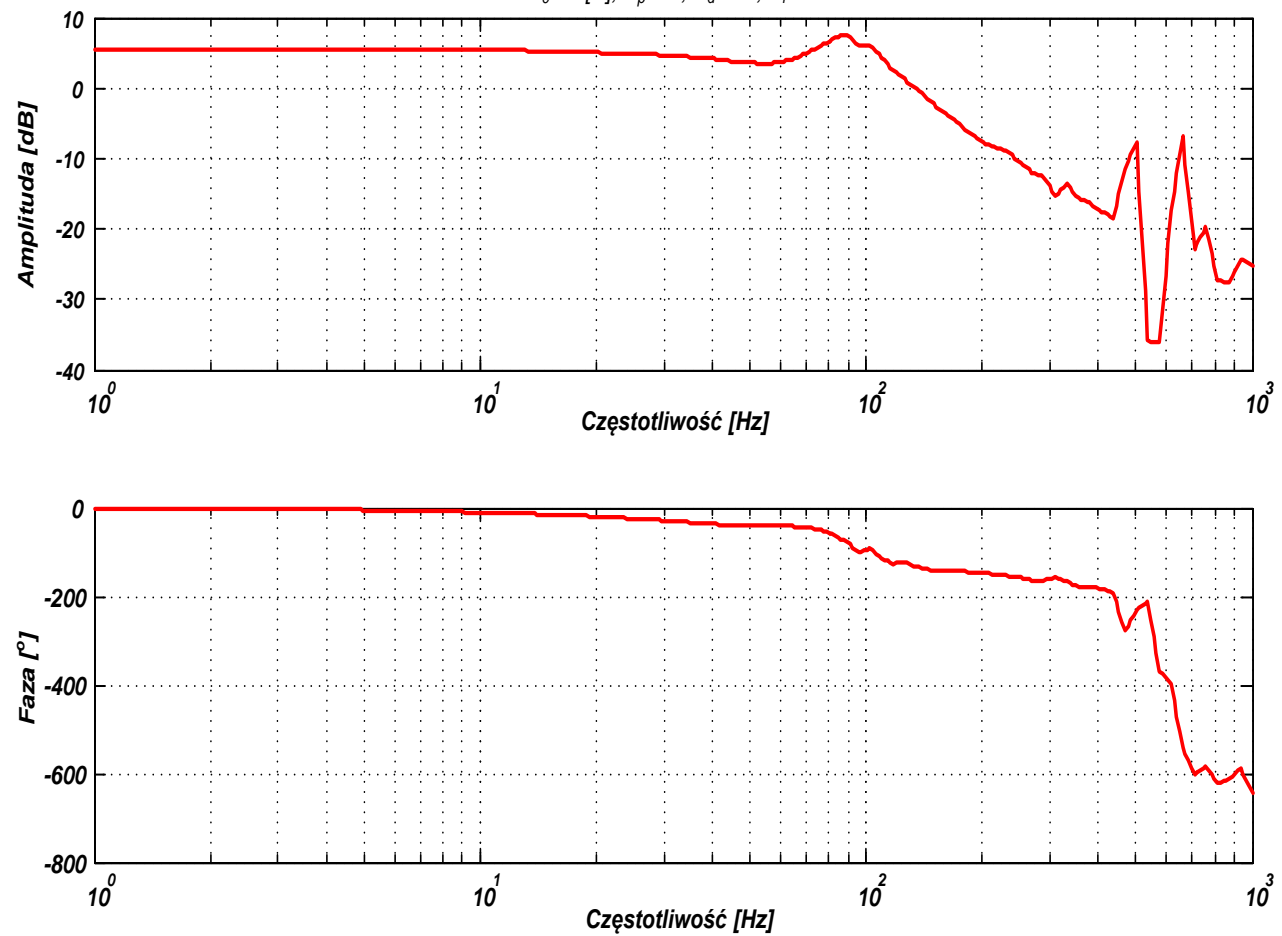

Rys. 6. Charakterystyka Bode'go uktadu zamkniętego z regulatorem PID.

\section{Aktywna redukcja drgań $\mathrm{z}$ zastosowaniem technologii zawieszeń magnetycznych}

$\mathrm{Na}$ bazie doświadczeń, zebranych podczas budowy stanowiska laboratoryjnego z samo łożyskującym się silnikiem elektrycznym oraz innych aplikacji z wykorzystaniem technologii łożysk magnetycznych, planuje się budowę stanowiska laboratoryjnego opartego na rzeczywistych komponentach silnika odrzutowego, a w konsekwencji budowę układu aktywnej redukcji drgań, pełniącego zarazem funkcję podpory, na silniku odrzutowym.

W tym celu zostanie wykorzystane aktywne łożysko, umieszczone jako podpora środkowa w silniku odrzutowym. Potencjalne miejsce zabudowy projektowanego 
zawieszenia magnetycznego $\mathrm{w}$ środkowej podporze silnika odrzutowego zaznaczono kolorem czerwonym, Rys. 7.

Do zrealizowania założonego celu zostanie wykorzystane aktywne łożysko magnetyczne. Łożyska tego typu posiadają unikatowe właściwości, których nie mogą spełnić stosując układy klasyczne. Podstawową zaletą zaproponowanego rozwiązania jest wykorzystanie aktywnego pola magnetycznego, którego wartość zależy od położenia wału wirnika $\mathrm{w}$ szczelinie powietrznej. W aktywnych systemach łożyskowania wirników wykorzystuje się promieniowe i różnicowe siłowniki elektromechaniczne. Siłownik taki zbudowany jest $\mathrm{z}$ dwóch elektromagnesów pracujących w układzie różnicowym i sterowanych zasilaczy / wzmacniaczy.
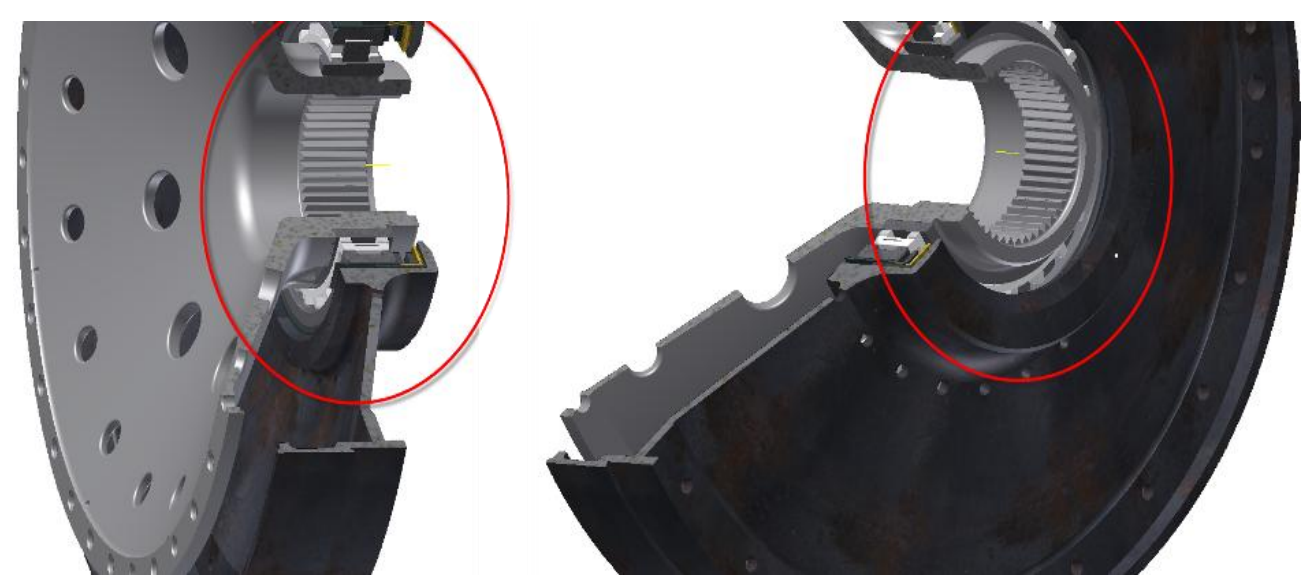

Rys. 7. Środkowa podpora silnika odrzutowego typu SO-3.

Zasilacze pełnią funkcję sterowanego źródła prądowego. Wartość prądu płynącego w cewkach elektromagnesów jest ustawiana przez regulator. W większości aplikacji używa się cyfrowych regulatorów pracujących w czasie rzeczywistym. Wartość prądu zmieniana jest przez regulator, gdy wał wirnika przemieści się względem położenia nominalnego (punktu pracy). Zmiana położenia wału wirnika rejestrowana jest przez bezkontaktowe czujniki przemieszczenia (np. czujniki wiroprądowe, optyczne).

Zasada działania łożyska magnetycznego, które w tym przypadku pełniło będzie również funkcję aktywnej redukcji drgań, przedstawiona jest na Rys. 8. Jeżeli wał wirnika znajduje się w położeniu nominalnym (Rys. 8a), to odległość między nabiegunnikami elektromagnesów do wirnika jest dokładnie taka sama i wynosi $x_{0}$. Wartość uchybu regulacji $e$ jest równa zeru, ponieważ wartość zadanego położenia i położenie rzeczywiste są identyczne. Wartość prądu 
zasilającego cewki elektromagnesów wynosi $i_{0}$. Każdy $\mathrm{z}$ elektromagnesów generuje siłę magnetyczną o tej samej wartości, ale o przeciwnych znakach, stąd wypadkowa wartość siły magnetycznej jest równa zero.

Jeżeli wirnik przemieści się z położenia nominalnego i zacznie zbliżać się do nabiegunnika elektromagnesu dolnego, to czujnik zarejestruje zmianę szczeliny powietrznej o wartość $x$ (Rys. 8b) $\rightarrow$ szczelina powietrzna powiększy się. Na wejście regulatora podana zostanie wartość uchybu regulacji o wartości ujemnej. Regulator wysteruje zasilacze w taki sposób, aby prąd w cewce elektromagnesu górnego zwiększył się, natomiast $\mathrm{w}$ cewce dolnej zmniejszył. Zmiana prądu odbywa się o taką samą wartość. Wraz ze zmianą wartości prądu, siła magnetyczna generowana przez górny elektromagnes rośnie, natomiast siła generowana przez dolny elektromagnes maleje. Wypadkowa siła magnetyczna rośnie i jest skierowana do góry, w taki sposób aby sprowadzić wał wirnika do położenia wyjściowego.

a)

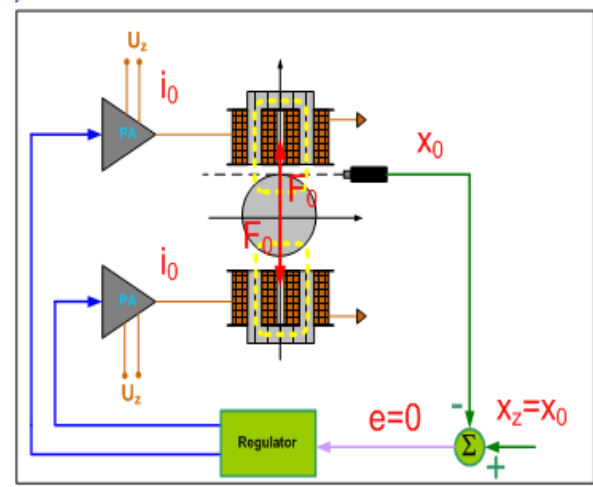

b)

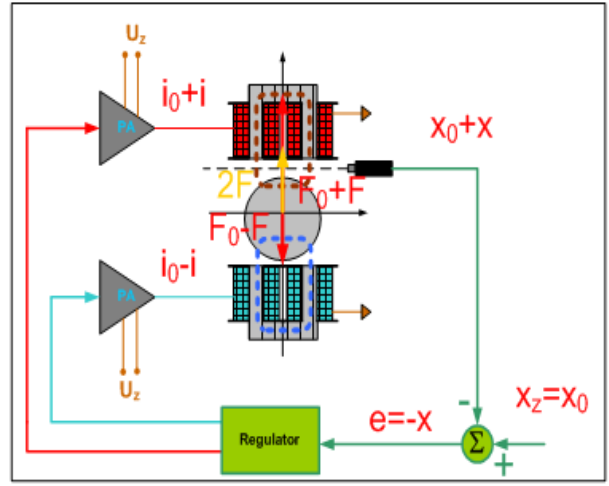

c)

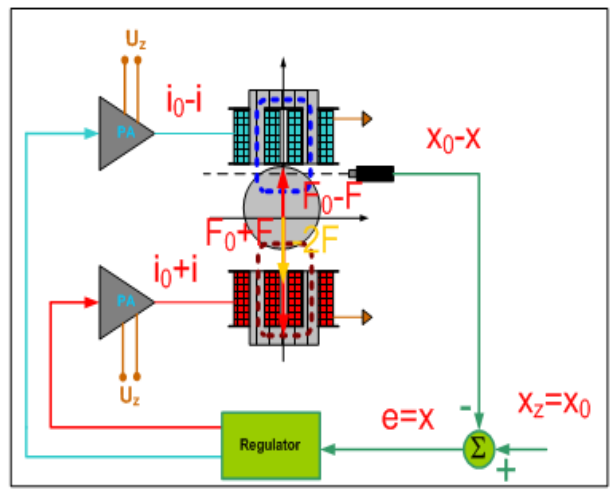

Rys. 8. Aktywne zawieszenie magnetyczne. 
Przy przesunięciu wału wirnika $\mathrm{w}$ przeciwnym kierunku (Rys. 8c), proces sterowania odbywa się analogicznie, z tą różnicą, że uchyb ma wartość dodatnią, co prowadzi do odwrócenia kierunku wypadkowej siły magnetycznej i wał wirnika w tym przypadku również zostanie sprowadzony do położenia wyjściowego.

$\mathrm{W}$ tak działającym łożysku magnetycznym czujnik mierzący położenie wirnika wraz z układem sterowania, realizuje sprzężenie zwrotne, między położeniem wirnika w szczelinie powietrznej a prądem sterującym. Aktywna zmiana siły magnetycznej może być wykorzystana do redukcji drgań i przenoszenia obciążeń.

Spełnienie powyższych oczekiwań wiąże się z zapewnieniem odpowiedniego pasma przenoszenia poszczególnych elementów łożyska magnetycznego. Zapewnienie tego pasma jest istotne przy zastosowaniu łożyska magnetycznego do aktywnej redukcji drgań wirnika.

Ponadto, mierząc zmienne procesowe niezbędne do sterowania łożyskiem, można oszacować wartości sił i przemieszczeń wirnika w płaszczyźnie łożyskowania. Poddając zarejestrowane sygnały dalszej obróbce w dziedzinie czasu i częstotliwości można wyposażyć dany obiekt techniczny w system diagnostyczny. Jak wynika $\mathrm{z}$ powyższego, łożysko magnetyczne może pełnić dodatkowo funkcję monitorowania stanu obiektu technicznego, na którym zostanie zainstalowany tego rodzaju układ.

\section{Podsumowanie}

Pozytywnie zakończone wyniki prac z zastosowaniem aktywnego zawieszenia magnetycznego $\mathrm{w}$ elektrycznym silniku samo łożyskującym się, są podstawą do rozwijania tej technologii $\mathrm{w}$ celu zastosowania $\mathrm{w}$ wymagających obiektach technicznych, jakimi są np. zespoły napędowe statków powietrznych jako układu aktywnej redukcji drgań, zawieszenia magnetycznego oraz monitoringu węzła kinematycznego. Należy mieć jednak na uwadze, że zastosowanie tego typu zawieszenia $\mathrm{w}$ obiekcie rzeczywistym musi zostać poprzedzone szeregiem prac laboratoryjnych, w tym budową modelu symulacyjnego takiego układu, opracowaniu modelu numerycznego, projekcie i wykonaniu stanowiska laboratoryjnego z rzeczywistymi zespołami silnika odrzutowego.

\section{Literatura}

[1] Chiba A., Fukao T., Ichikawa O., Oshima M., Takemoto M., Dorrel D.: Magnetic Bearings and Bearingless Drives, Elsevier's Science Technology Rights Department in Oxford, UK, 2005;

[2] Żokowski M.: Projektowanie i badanie samołożyskującego się wirnika silnika elektrycznego, Rozprawa doktorska napisana pod kierunkiem prof. dr. hab. inż. Z Gosiewskiego, Warszawa, 2011; 
[3] Opracowanie zespołu Zakładu Silników Lotniczych ITWL zrealizowane pod kierownictwem dr. inż. J. Spychały: Demonstrator systemu diagnozowania systemu zespołu wirnikowego silnika odrzutowego, Warszawa, 2011.
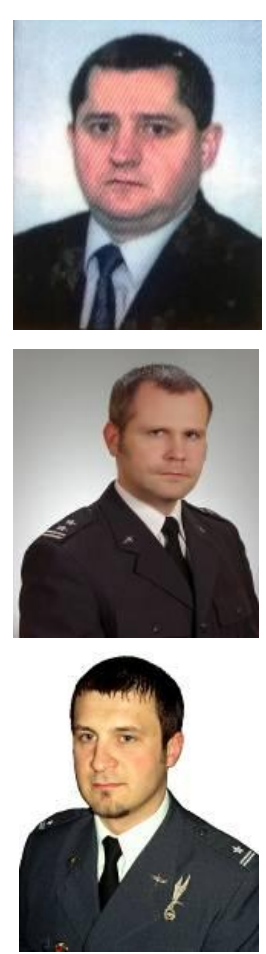

dr inz. Jarostaw Spychata - absolwent Wojskowej Akademii Technicznej (1987) - specjalność: samoloty i śmigłowce. Od 1988r. pracownik ITWL, od 2004 r. kierownik Zaktadu Silników Lotniczych w ITWL.

pptk mgr ini. Pawet Majewski - absolwent Wojskowej Akademii Technicznej (1997) - specjalność: automatyka i diagnostyka lotnicza, absolwent studiów podyplomowych Politechniki Warszawskiej (2002) - specjalność projektowanie systemów informatycznych. Żolnierz zawodowy. Od 1999 r. pracownik ITWL, obecnie na stanowisku kierownika Pracowni Diagnostyki w Zakładzie Silników Lotniczych.

mjr dr inż. Mariusz Żokowski - absolwent Wojskowej Akademii Technicznej (2003) - specjalność: osprzęt samolotów $i$ śmigłowców, absolwent Politechniki Warszawskiej (2004) specjalność: elektrotechnika, absolwent studiów doktoranckich Politechniki Koszalińskiej (2008). Żotnierz zawodowy. Od 2007 r. pracownik ITWL, obecnie na stanowisku kierownika pracowni $w$ Zaktadzie Silników Lotniczych. 